\title{
NUTRIENT CONTENT OF FENUGREEK (TRIGONELLA FOENUM-GRAECUM L.) ON THE EFFECT OF DIFFERENT FERTILIZATION TREATMENTS
}

\author{
Viktor József Vojnich ", Attila Hüvely, András Palkovics, Judit Petö \\ Department of Agricultural Sciences, Faculty of Horticulture and Rural Development, John von Neumann \\ University, Hungary \\ https://doi.org/10.47833/2020.1.AGR.012
}

\section{Keywords:}

Fenugreek (Trigonella foenumgraecum L.)

macro elements

magnesium treatments

open-field

fertilizer

$\begin{array}{lr}\text { Article history: } \\ \text { Received } & \text { 7 Nov } 2019 \\ \text { Revised } & 28 \text { Nov } 2019 \\ \text { Accepted } & 5 \text { Dec } 2019\end{array}$

\section{Introduction}

Fenugreek (Trigonella foenum-graecum L.) belonging to the legumes (Fabaceae) family is an annual plant [1]. Leaves are like alfalfa, the leaves are scattered along the stem [2]. The plant is primarily self- pollinating, but can also be extraneous pollinating [3]. Mediterranean, native to the Mediterranean coast. It is cultivated as a spring-sown plant in temperate climate countries. It is grown as an autumn sown plant in Egypt, Morocco and India [4]. A multiuse plant that is used as an herb, spice and fodder plant. In Hungary, Sámuel Diószegi and Mihály Fazekas published the Hungarian Phenomenon in 1807 as a wild herb [5]. Hungary before 1945 years, the southern part of the country was cultivated fenugreek, horticultural crops. Later, in 1969-1970, the Tápiószelei Agrobotany Institute started the experimental cultivation. From 1982, research on the technology of cultivating fenugreek and the production of new, intensive varieties began in Mosonmagyaróvár. Then in 1987, a new Hungarian fenugreek breed has been generated, known under the name "Óvári-4". This variety was accepted by the state later, in 1994.

It is mainly used to promote digestion, compress inflammation, fattening, and milk selection. In North America, the settlers took fenugreek and used as fodder plant. The T. foenum-graecum crop has several advantages. Rhisobium meliloti is a nitrogen-binding bacterium on its roots that can bind about 70-90 kg/ha of nitrogen in the soil [4]. Due to its high protein content, fenugreek is well suited for feeding of domestic and wild animals.

Our experiment was set with different fertilization treatments; the aim of which is to show how nutritional values of the stem and leaves are changing.

\footnotetext{
* Corresponding author. Tel.: +36 76517623

E-mail address: vojnich.viktor@kvk.uni-neumann.hu
} 


\section{Material and methods}

The experiment was carried out in the pilot farm of John von Neumann University, Faculty of Horticulture and Rural Development, in Kecskemét, Hungary in 2018. Our test plant was fenugreek (Trigonella foenum-graecum L.). In the course of the open field trials different nutrient doses were applied. Seed sowing was performed in open field on $9^{\text {th }}$ of April 2018. The treatments were carried out in plots of $50-50 \mathrm{~m}^{2}$, according to the following methods: treatment $1=150 \mathrm{~kg} \mathrm{Ha}^{-1}$; treatment 2 $=300 \mathrm{~kg} \mathrm{Ha}^{-1}$; treatment $3=450 \mathrm{~kg} \mathrm{Ha}^{-1}$ complex base fertilizer. Mechanical weed control was applied. No chemicals or herbicides were applied. The harvest took place from June $25^{\text {th }}$ to July $9^{\text {th }}$.

The soil analysis of the experimental area (Table 1) and its evaluation was carried out by Soil and Plant Testing Laboratory of Faculty of Horticulture and Rural Development (Kecskemét).

Table 1. Soil characteristics of the experimental area (2018)

\begin{tabular}{|c|c|c|}
\hline Denomination & Measurement unit & Value \\
\hline $\mathrm{pH}_{\mathrm{kCL}}$ & - & 7.61 \\
\hline $\mathrm{K}$ & - & 28 \\
\hline Water soluble salt & $\mathrm{m} / \mathrm{m} \%$ & $<0.02$ \\
\hline $\mathrm{Humus}$ & $\mathrm{m} / \mathrm{m} \%$ & 1.43 \\
\hline $\mathrm{CaCO}_{3}$ & $\mathrm{~m} / \mathrm{m} \%$ & 2.62 \\
\hline $\mathrm{NO}_{2}-\mathrm{NO}_{3}-\mathrm{N}$ & $\mathrm{mg} / \mathrm{kg}$ & 1.43 \\
\hline $\mathrm{P}_{2} \mathrm{O}_{5}$ & $\mathrm{mg} / \mathrm{kg}$ & 548 \\
\hline $\mathrm{K}_{2} \mathrm{O}$ & $\mathrm{mg} / \mathrm{kg}$ & 104 \\
\hline $\mathrm{Mg}$ & $\mathrm{mg} / \mathrm{kg}$ & 106 \\
\hline $\mathrm{Na}$ & $\mathrm{mg} / \mathrm{kg}$ & 6.61 \\
\hline $\mathrm{Cu}$ & $\mathrm{mg} / \mathrm{kg}$ & 13.1 \\
\hline $\mathrm{Mn}$ & $\mathrm{mg} / \mathrm{kg}$ & 55 \\
\hline $\mathrm{Zn}$ & $\mathrm{mg} / \mathrm{kg}$ & 9.72 \\
\hline $\mathrm{Fe}$ & $\mathrm{mg} / \mathrm{kg}$ & 64.1 \\
\hline $\mathrm{SO}$ & $\mathrm{mg} / \mathrm{kg}$ & 8.4 \\
\hline
\end{tabular}

Fertilizer used in research: NovaTec premium 15-3-20 (+2MgO+10S) + TE. Technical data of fertilizer: $15.0 \%$ total nitrogen $(\mathrm{N}) ; 8.0 \%$ ammoniacal nitrogen $\left(\mathrm{NH}_{4}-\mathrm{N}\right) ; 7.0 \%$ nitrate nitrogen $\left(\mathrm{NO}_{3}-\right.$ $\mathrm{N}) ; 0.0 \%$ carbamide nitrogen $\left(\mathrm{NH}_{2}-\mathrm{N}\right) ; 3.0 \%$ phosphate $\left(\mathrm{P}_{2} \mathrm{O}_{5}\right)$ soluble in neutral ammonium citrate and water; $2.4 \%$ phosphate $\left(\mathrm{P}_{2} \mathrm{O}_{5}\right)$, water soluble; $20.0 \%$ potassium oxide $\left(\mathrm{K}_{2} \mathrm{O}\right)$, water soluble; $2.0 \%$ total magnesium oxide (MgO); $1.6 \%$ magnesium oxide $(\mathrm{MgO})$, water soluble; $10.0 \%$ total sulphur (S); $8.0 \%$ sulphur $(\mathrm{S})$, water soluble; $0.02 \%$ total boron $(\mathrm{B}) ; 0.0 \%$ total copper $(\mathrm{Cu}) ; 0.06 \%$ total iron $(\mathrm{Fe}) ; 0.0 \%$ total manganese $(\mathrm{Mn}) ; 0.01 \%$ total zinc $(\mathrm{Zn}) ; 0.8 \%$ nitrification inhibitor 3.4-dimethylpyrazole-phosphate (DMPP) related to total of $\mathrm{NH}_{4}-\mathrm{N}$ and $\mathrm{NH}_{2}-\mathrm{N}$; low in chlorine (Cl).

Physical properties: 1, physical appearance: solid, granulated; 2, colour: purple; 3, bulk density: $1,250 \pm 100 \mathrm{~kg} / \mathrm{m}^{3} ; 4$, granulometry: $90 \%=2-4 \mathrm{~mm} ; 5$, average granule size (d50): $3.2 \pm$ $0.4 \mathrm{~mm} ; 6, \mathrm{pH}$ (1:10 in water): 4.5-5.5 [6].

Leaf- and stem samples were dried at $70{ }^{\circ} \mathrm{C}$. The air-dry samples were thoroughly minced. For elemental studies powdered samples were digested in a microwave device by means of concentrated nitric acid and hydrogen peroxide (Milestone Ethos Plus). Macro element content was measured by optical emission spectrometer (ICP-AES method) [7]. Nitrogen content in leaf and stem was determined using the Kjeldahl method after sulphuric acid digestion (FOSS Kjeltec 2300). Macro element ( $\mathrm{N}, \mathrm{P}, \mathrm{K}, \mathrm{Ca}, \mathrm{Mg}$, Na) contents were calculated in $\mathrm{m} / \mathrm{m} \%$ dry matter.

The required tests were made according to the regulation including measurement of the $N, P$, $\mathrm{K}, \mathrm{Ca}, \mathrm{Mg}$ content. 


\section{Results}

During the study we determined $(\mathrm{m} / \mathrm{m} \%$ dry matter) the concentration of some nutrients (nitrogen, magnesium, calcium, potassium and phosphorus) of fenugreek in the parts of the plants above the ground (stem, leaf) (Figure 1). For all three treatments $\left(150-, 300\right.$ - and $\left.450 \mathrm{~kg} \mathrm{Ha}^{-1}\right)$, the highest macro element values were measured for nitrogen (from $2.91 \mathrm{~m} / \mathrm{m} \%$ till $3.5 \mathrm{~m} / \mathrm{m} \%$ ) and calcium (from $2.75 \mathrm{~m} / \mathrm{m} \%$ till $3.44 \mathrm{~m} / \mathrm{m} \%$ ) in dry matter. The Treatment 1, Treatment 2 and Treatment 3 were measured the lowest macro element values for phosphorus (from $0.31 \mathrm{~m} / \mathrm{m} \%$ till $0.53 \mathrm{~m} / \mathrm{m} \%$ ) and magnesium (from $0.40 \mathrm{~m} / \mathrm{m} \%$ till $0.47 \mathrm{~m} / \mathrm{m} \%$ ) in dry matter.

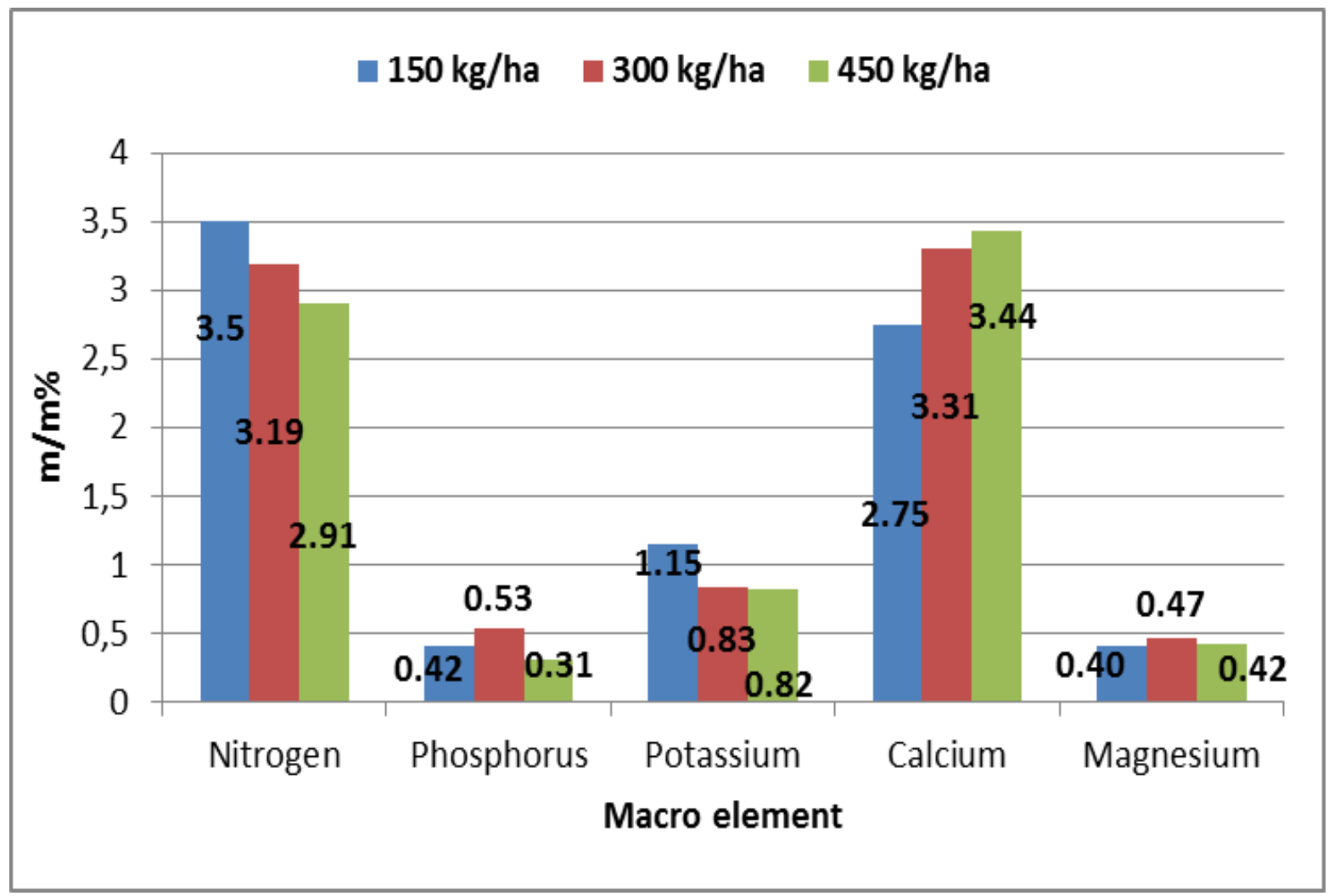

Figure 1. Macro element ( $\mathrm{N}, \mathrm{P}, \mathrm{K}, \mathrm{Ca}, \mathrm{Mg}, \mathrm{Na})$ contents were calculated in $\mathrm{m} / \mathrm{m} \%$ dry matter.

The spring-type $T$. foenum-graecum can be harvested in 80-90 days after seeding (Figure 2). 


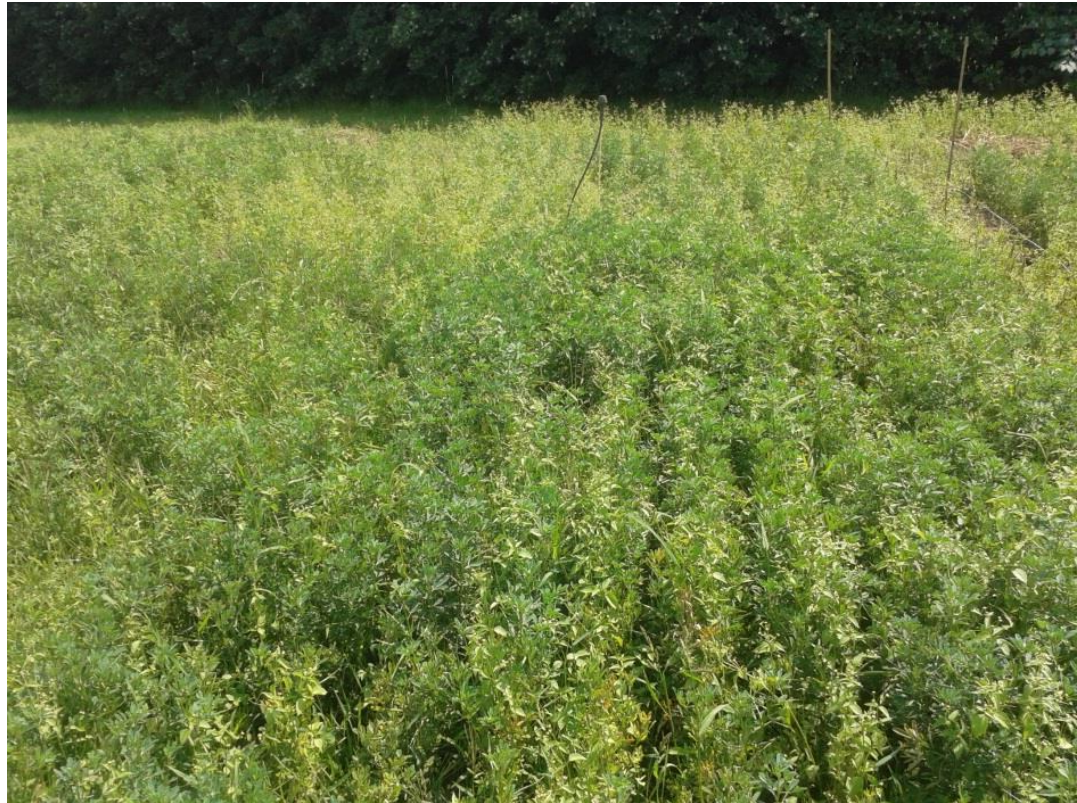

Figure 2. Fenugreek stock on 4th of June 2018.

\section{Conclusions}

The aim of the treatments is to show how macro element (nitrogen, magnesium, calcium, potassium and phosphorus) values ( $\mathrm{m} / \mathrm{m} \%$ dry matter) of the stem and leaves are changing.

The calcium content in the dry matter $(\mathrm{m} / \mathrm{m} \%)$ increased linearly from Treatment $1(150 \mathrm{~kg} \mathrm{Ha}$ $\left.{ }^{1}\right)$ to Treatment $3\left(450 \mathrm{~kg} \mathrm{Ha}^{-1}\right)$ in the examined fenugreek stems and leaves. The highest calcium was $3.44 \mathrm{~m} / \mathrm{m} \%$ in Treatment 3.

In the tested $T$. foenum-graecum plants, nitrogen and potassium contents of air-dry substance $(\% \mathrm{~m} / \mathrm{m})$ decreased steadily by increasing the fertilizer doses from $150 \mathrm{~kg} \mathrm{Ha}^{-1}$ to $450 \mathrm{~kg} \mathrm{Ha}^{-1}$. The highest nitrogen was $3.50 \mathrm{~m} / \mathrm{m} \%$ in Treatment 1 . The value of highest potassium contents was in Treatment $1(1.15 \mathrm{~m} / \mathrm{m} \%)$.

After the initial growth, phosphorus and magnesium concentration decreased with increasing fertilizer use.

For all three treatments $(150-, 300-$ and $450 \mathrm{~kg} \mathrm{Ha}-1)$, were measured the lowest macro element values for phosphorus (from $0.31 \mathrm{~m} / \mathrm{m} \%$ till $0.53 \mathrm{~m} / \mathrm{m} \%$ ) and magnesium (from $0.40 \mathrm{~m} / \mathrm{m} \%$ till $0.47 \mathrm{~m} / \mathrm{m} \%$ ) in dry matter.

\section{Acknowledgment}

We thank the support of research that "development of functional, healthy and safe food product chain model based on the principle table, thematic research networks from the field," the EFOP-3.6.2-16-2017-00012 realized under the project of the John von Neumann University.

\section{References}

[1] PROVOROV, H.A. (1985): Izomencsivoszty rasztenij nazsitnyika grecseszkovo (Trigonella foenum-graecum L.) po szpaszbnosztyik szimbiozusz klubenkovümi bakterijami lucernü Buluten vszecajuznovo naucsnoIsszledovatyelszkovo Insztiuta Szelszkohozjajszvennoj Mikrobiologii. 41:21-213.

[2] VAN WYK, B.E. (2005): Handbuch der Nahrungspflanzen. Wissenschaftliche. Verlagsgesellschaft, Stuttgart. pp. $15,367$.

[3] SALVATORE, D.G. (1951): Ricerhe sui consumi idrici e indogini sull autofertilita del feno greco stazione. Agraria Sperimentale, Bari. pp. 1272-1286.

[4] MAKAI S., PÉCSI, S., KAJDI, F. (1996): A görögszéna (Trigonella foenum-graecum L.) termesztése és hasznosítása. Környezet- és Tájgazdálkodási Füzetek. 1996, Vol. 4. pp. 32-35. 
[5] MAKAI, P.S., MAKAI, S. (2004): Görögszéna (Trigonella foenum-graecum L.) fajták terméseredményeinek összehasonlítása és az optimális csíraszám meghatározása. Acta Agronomica Óvariensis, 46(1):17-23.

[6] http://www.compo-expert.com

[7] HÜVELY, A. (2005): Az ICP, vagyis az emissziós analízis lehetőségei című előadás/ A Magyar Tudomány Ünnepe, Megyei Tudományos Fórum/ Kecskeméti Főiskola/ Kertészeti Főiskolai Kar/ Kecskemét. pp. 102-105. 